\title{
Trends and constraints of utilization of preserved cowpea leaves among households in arid and semi-arid lands in Kenya: a convergent mixed method study
}

\author{
J. O. Owade ${ }^{1^{*}}$ D , G. O. Abong' ${ }^{1}$, M. W. Okoth ${ }^{1}$ and A. W. Mwang'ombe ${ }^{2}$
}

\begin{abstract}
Background: As much as local communities have employed traditional techniques of preservation to enhance availability and utilization of cowpea leaves, the efficiency of these techniques in achieving food security need to be established. The current study sought to document trends and constraints of utilization of preserved cowpea leaves in the arid and semi-arid lands (ASALs) in order to overcome of seasonal availability of the vegetable.

Method: A mixed method convergent design that included household survey of randomly sampled cowpea producing households and focus group discussion and key informant interviews with stakeholders in the ASAL areas of Kitui and Taita Taveta Counties of Kenya was conducted.

Results: The study found that the utilization of preserved forms of cowpea leaves in the in-season was by $58 \%$ of the respondents. Three quarters (73.6\%) of the households could not get the vegetables from their own sources during scarcity, whereas $25 \%$ did not consume the vegetables at all at such times. The preserved forms of the vegetables was utilized among $24.0 \%$ of the households, with significantly $(p<0.05)$ higher utilization in less arid areas. Households that were involved in commercialization of cowpea leaves and sale of the preserved forms in the open air market had significantly higher likelihood ( $p<0.001, \mathrm{O}=2.47$ and $p<0.001, \mathrm{OR}=2.3$, respectively) of utilization of the vegetables during scarcity. Emerging themes from the qualitative survey showed that weaknesses in the policy environment, stakeholder interest, marketing and accessibility to proper equipment were the deterrents of traditional preservation of the vegetable.
\end{abstract}

Conclusion: In conclusion, the preserved forms of cowpea leaves promoted availability of the vegetable especially in the dry seasons. In as much as there is limited practising of preservation of the vegetables, its availability is enhanced through dehydration and other value-addition techniques among a significant number of the households.

Keywords: Traditional, Drying, Cowpea leaves, Availability, Utilization

*Correspondence: owadehjm@gmail.com

${ }^{1}$ Department of Food Science, Nutrition and Technology, University of Nairobi, P.O. Box 29053-00625, Nairobi, Kenya

Full list of author information is available at the end of the article

\section{Background information}

Cowpea (Vigna unguicuata (L.) Walp) is a drought tolerant crop that is well suited for cultivation across diverse agro-ecological zones (Drahansky et al. 2016). The crop is a dual purpose for it is grown both for its grains and leaves especially in sub-Saharan Africa, SSA (MuñozAmatriaín et al. 2017). In Kenya, the crop has been grown original author(s) and the source, provide a link to the Creative Commons licence, and indicate if changes were made. The images or other third party material in this article are included in the article's Creative Commons licence, unless indicated otherwise in a credit line to the material. If material is not included in the article's Creative Commons licence and your intended use is not permitted by statutory regulation or exceeds the permitted use, you will need to obtain permission directly from the copyright holder. To view a copy of this licence, visit http://creativecommons.org/licenses/by/4.0/. The Creative Commons Public Domain Dedication waiver (http://creativeco mmons.org/publicdomain/zero/1.0/) applies to the data made available in this article, unless otherwise stated in a credit line to the data. 
mainly in the arid and semi-arid lands (ASALs), including in eastern and coastal counties (Njonjo et al. 2019; Owade et al. 2020a); for instance Taita Taveta and Kitui counties accounted for a total of $43.16 \%$ of the national production quantities of cowpea leaves of $3941 \mathrm{MT}$ (Horticultural Crops Directorate 2016). These areas are characterized with adverse weather conditions limiting crop cultivation and production either for commercial or subsistence (County Government of Kitui 2018; County Government of Taita Taveta 2018). The two counties constitute regions with a high vulnerability to food insecurity due to regular exposure to drought and price fluctuation of commodities (UNICEF 2018). Moreover, disease burdens resulting from micronutrient deficiencies such as anaemia that is caused by poor dietary intake of iron are prevalent in the regions (Odhiambo and Sartorius 2020). This is because the households are exposed to limited diet diversification as a result of crop failures caused by lengthened periods of drought. Additionally, the rural areas in country including the two ASAL counties have been reported to have higher rates of vitamin A deficiency (KNBS et al. 2014).

Cowpea leaves is renowned for complementing the diets of communities in these malnutrition hotspots that mainly comprises starchy grains (Owade et al. 2020a). The vegetable is rich in micronutrients such as iron, zinc, calcium and beta-carotene which constitute some of the limiting nutrients in the diets of food insecure households (Odhiambo and Sartorius 2020; Owade et al. 2020b). Additionally, its suitability in these areas is due to a variety of traits it displays including early maturity, thus they complete reproductive cycles before the onset of drought (Huynh et al. 2018). Recent studies point to interest in increasing productivity of the crop in order to harness more benefits from the leaves and grains (Huynh et al. 2018; Lo et al. 2018).

The greatest limitation to the utilization of cowpea leaves is the seasonality in their production (Kirakou et al. 2017), that is in the season of glut there is high postharvest losses; however, during drought there is scarcity (Kirigia et al. 2018). Local communities have come up with traditional processing techniques aimed at enhancing availability of the vegetables even during seasons of drought (Owade et al. 2020b); however, the efficiency of these techniques in promoting the availability of the vegetables among these vulnerable households is yet to be determined. Among resourced communities, techniques of solar and oven drying have been used in processing of dehydrated vegetables; however, the resource-constrained settings have utilized open sun-drying deeming it affordable (Owade et al. 2020a). A study done in Uganda showed that the consumer acceptability of preserved cowpea leaves did not significantly differ across different traditional processing techniques that included open sun-drying and blanching (Natabirwa et al. 2016). Despite the challenge of reduction in nutrient composition such as beta-carotene and ascorbic acid contents in the dehydrated leaves, retained nutrients in the vegetables have been found to be sufficient enough to address limited intake of these micronutrients among populations (Owade et al. 2020b). Additionally, the study found that traditional preservation of cowpea leaves did not significantly alter the proximate composition of the leaves. This study has the implication that traditional processed cowpea leaves can be possible alternatives for nutrition in cases of scarcity. Moreover the abundant production of the vegetable in these areas make it a feasible strategy in addressing the high malnutrition rates such as iron deficiency that are often reported (KNBS et al. 2014, Horticultural Crops Directorate 2016). The study therefore sought to evaluate the utilization of preserved cowpea leaves as a complementary of fresh forms in effort to promote the off-season availability of the vegetables among households in ASAL areas.

\section{Materials and methods Study design}

A mixed method convergent design that included a crosssectional survey of households, key informant interviews (KII) and focus group discussion (FGD) was used for data collection in the ASAL counties of Kitui (eastern) and Taita Taveta (coastal) in Kenya, see Fig. 1, between April and June 2019. KII was conducted with agricultural officers whereas the FGD was done with farmer groups in the two counties.

\section{Description of the study areas}

Taita Taveta County is located between the latitudes $2^{\circ} 30^{\prime}$ and $4^{\circ} 30^{\prime}$ South and the longitudes $37^{\circ} 36^{\prime}$ and $39^{\circ} 14^{\prime}$ East whereas Kitui County is located between the latitudes $0^{\circ} 10^{\prime}$ South and $3^{\circ} 0^{\prime}$ South and the latitudes $37^{\circ} 50^{\prime}$ East and $39^{\circ} 0^{\prime}$ East (County Government of Kitui 2018; Mwakesi et al. 2020). The two counties rank among the highest cowpea leaves producing ASAL areas in the country (USAID and AFFA 2014; Horticultural Crops Directorate 2016; Owade et al. 2020b). Kitui County have higher temperatures and more erratic and unreliable rainfall than Taita Taveta County, thus has severer arid conditions (County Government of Kitui 2018; County Government of Taita Taveta 2018). The county has her lowest and highest annual average temperatures at $14{ }^{\circ} \mathrm{C}$ and $32{ }^{\circ} \mathrm{C}$, respectively, with an annual rainfall of 500 $1050 \mathrm{~mm}$ across the long rains of between March and May and short rains of between October and December (Government of Kenya 2016; County Government of Kitui 2018). Major crops cultivated in the Kitui County 


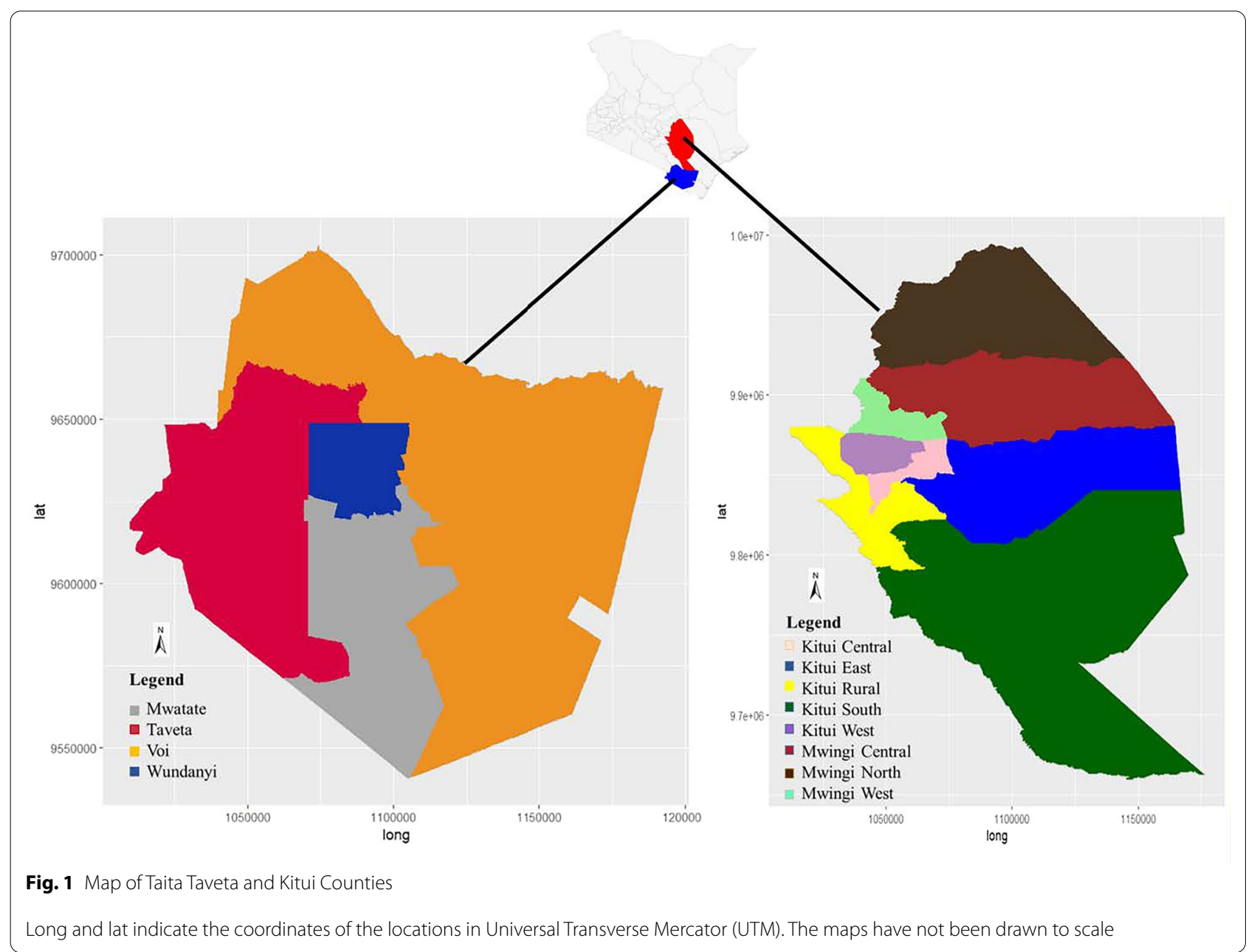

include maize, sorghum, millet, and legumes such as cowpea and pigeon peas and root crops (County Government of Kitui 2018).

In Taita Taveta County, the long rains are usually experienced between March and May, with an average, $265 \mathrm{~mm}$ and $157 \mathrm{~mm}$ in highlands and lowlands, respectively, and short rains are between October and December, with annual rainfall being recorded at $1200 \mathrm{~mm}$ in the highlands and $341 \mathrm{~mm}$ in the lowlands (County Government of Taita Taveta 2018). The county has a temperature range of $18-25{ }^{\circ} \mathrm{C}$ across the year. The major crops cultivated in the area include cereals such as maize, rice and sorghum; pulses such as beans, cowpeas, green grams and pigeon peas; root crops; and horticultural crops.

\section{Data collection}

\section{Sampling technique}

Mwingi Central Sub-County in Kitui County and Mwatate and Wundanyi Sub-Counties in Taita Taveta
Counties which were the cowpea producing subcounties in the respective counties were purposively selected; for Kitui and Taita Taveta counties were ranked among the major cowpea producing areas in Kenya (Horticultural Crops Directorate 2016). The sampling units from which the households were drawn were the all the wards within the sub-counties. The sample drawn from each Ward was determined in proportion of the projected population as per County Government of Kitui (2018) and County Government of Taita Taveta (2018). A sample of 405 cowpea producing and consuming households determined as per Yamane 1967:886 formulae, as explained by Israel (1992), were selected using systematic random sampling (Eq. 1); 205 of the households were sampled from Taita Taveta County and 200 househols from Kitui County. The first of every three households were included in the sampling frame in order to effect randomization of the selected households in the study. 


$$
n=\frac{N}{1+N(e)^{2}},
$$

where $N(276,581)$ is the total number of households in the two counties as per Kenya National Bureau of Statistics (KNBS) (KNBS 2014) and $e$ is the maximum variability $(0.05)$ permitted. Thus,

$$
n=\frac{276581}{1+276581(0.05)^{2}}=399.42(400) .
$$

\section{Data collection tools and methods}

A semi-structured questionnaire was loaded in the mobile-enabled application, open data kit (ODK), and was first pretested in Wundanyi town, Taita Taveta County, among households which were not to be part of the survey. Corrections to the questionnaire and coding of more responses were done based on the shortfalls noted during the pretesting. Enumerators who had attained tertiary level of education were trained on administration of the questionnaire to enhance the quality of the data. Data collection was then administered in the local language (Swahili) on randomly selected households. Informed consent from the respondents was first obtained before administration of the questionnaire. Information regarding the socio-demographic and economic characteristics, production, availability and utilization practices of fresh and preserved forms of cowpea leaves was collected.

\section{Data collection for qualitative survey}

Qualitative surveys including key informant interviews (KII) and focus group discussions (FGD) were conducted among the stakeholders in the cowpea value-chain in the area for mutual validation and convergence with the findings from quantitative surveys. Informed consent of these respondents was first obtained before participation. The respondents were purposively selected based on their role in the cowpea leaves value-chain. The key informants had an average of $41.2 \pm 5.6$ years whereas the FGD participants had $39.2 \pm 8.1$ years. Two participants from each of the categories of farmers, farmer group leaders, extension officers and county officers were selected as key informants. On the other hand, the FGD had group members, non-group members and farmer group leaders constituting 9, 5 and 6 of the participants, respectively $(n=20)$. Of the participants in the FGD, 16 were females whereas 4 were males $(n=20)$.

\section{Statistical analysis of quantitative data}

The quantitative data was analysed using $\mathrm{R}$ programming language (R Core Team 2019). Descriptive statistics including mean and standard deviation for continuous variables and frequencies in the case of categorical variables of the socio- demographic data were generated. With the availability and utilization of fresh and preserved cowpea leaves as the dependent variables, inferential statistical tests including linear modelling, chi-square tests and odds ratios were used to establish associated and predictive factors from the agricultural and socio-demographic independent variables.

Correspondence analysis was used to establish the trends in and relationship of the availability, sourcing and utilization of cowpea leaves in the producing households as shown in Eq. (2).

$$
\operatorname{dist}\left(v_{1}, v_{2}\right)=\sum \frac{\left(v_{1} \text { profile }-v_{2} \text { profile }\right)^{2}}{\text { average profile }}
$$

where $v$ exists in $v_{1}, v_{2} \ldots . . v_{n}$ and average profiles are calculated as

$$
\begin{aligned}
& v \text { profile }=\frac{x}{\Sigma_{n}^{1}(x)}, \\
& \text { average profile } \rightarrow \frac{\sum_{p}^{1} x}{\sum_{p}^{1}\left(\Sigma_{n}^{1}(x)\right)},
\end{aligned}
$$

where $v$ represent variables (availability, sourcing and utilization of cowpea leaves), $x$ a consistent value to represent a category such as "Yes" or "No" for a variable v; and $n$ and $p$ as total number of variables and households, respectively.

\section{Thematic analysis of qualitative data}

Thematic analysis of the qualitative data was done using the social sciences queries technique as explained by Ryan and Bernard (2003) to identify emerging themes. Since the quantity of the data was not that large, the analysis was done in the Microsoft word following a six step criteria: 1 . Assigned labels, also known as anchor codes, based on the questions asked in the survey; 2. Identified relevant statements in the data and assigned specific codes under respective anchor codes; 3 . Compiled a list of the initial codes that had been formulated; 4 . The codes were arranged alphabetically under their respective anchor codes; 5 . All the codes were grouped and tallied based on frequency of occurrence; 6 . From these the emerging themes were generated by checking on the frequency of mention, relationships and underlying concepts in the codes.

\section{Results and discussion}

Socio-economic and demographic characteristics of households in the cowpea growing ASALs

The household heads were mainly males (72.3\%). Among the household heads, $30.2 \%$ did not have any form of 
formal education, $48.5 \%$ with primary education and $21.8 \%$ attained secondary level and beyond with no significant differences $(\mathrm{p}>0.05)$ among the two ASAL areas. A comparison of the two counties found that the eastern ASALs $(6.8 \pm 3.1$ persons $)$ had significantly $(\mathrm{p}<0.001)$ larger households sizes than the coastal ASALs ( $3.4 \pm 2.2$ persons), results which are in agreement with the 2019 national census data (KNBS 2019). Thematic analysis of the key informant interview and focus group discussions data found four emerging themes (Additional files 1 and 2). A triangulation technique was used in the presentation of the results of the emerging thematic areas from the qualitative data and the statistics from the quantitative study.

\section{Theme 1: Trends and constraints of utilization and availability of fresh cowpea leaves}

In sourcing of the vegetables in the in-season, almost all households (97.5\%) sourced them from the farm; with complementary sources being the market and roadside vendors where $22.2 \%$ and $20.0 \%$, respectively, sourced their vegetables too. Significantly $\left(x^{2}=10.0, d f=1\right.$, $\mathrm{p}=0.002$ ) higher proportion of the households from eastern ASAL areas (100\%) than coastal ASAL areas (95.0\%) sourced the cowpea leaves from the farm as shown in Fig. 2. The low dependence of marketing avenues for sourcing of these vegetables point out a prevalent problem that has been identified as a constraint in the promotion of African Leafy Vegetables (ALVs) as food security crops in these malnutrition hotspots (Krause et al. 2019); limited commercialization and low profitability in the value chains that hinder adoption of the crops. In the utilization of the fresh leaves, majority (85.7\%) of the households from both study areas utilized the vegetable singly rather than as a composite with other vegetables (Fig. 3). More households in coastal ASALs (95.6\%) consumed the vegetable singly than those in eastern ASALs (76.0\%);

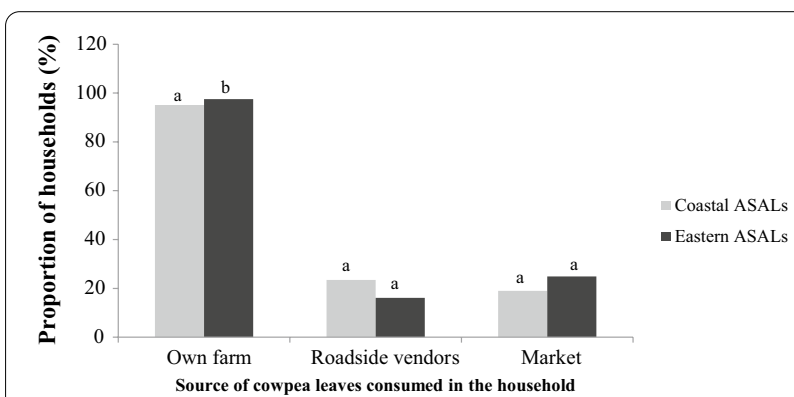

Fig. 2 Source of cowpea leaves consumed in the households producing cowpea leaves in the arid and semi-arid lands. Vertical bars for the same group label marked with different letters ( $a$ and $b$ ) at the top denote significant difference of the values at $p<0.05$ whereas in the latter, more households (75\%) mashed and mixed it with other foods than in the former. The finding deviates from that established by a similar study done in Tanzania by Mduma (2010) that reported multiple cuisines for the vegetable. Other studies have also reported more traditional preparation techniques including boiling with lye, boiling with coconut milk and addition of cow milk and frying which are not practised in the current study areas (Akello 2014; Okello et al. 2015; Owade et al. 2020b). Even with the limited diversification, the farmers corroborated that nutritional composition of cowpea leaves served as a major selling point for the utilization in households. The vegetable has $32.74-36.55$, $70-203,66-75,17.1-39.87$ and $5.22-12.91 \mathrm{mg} / 100$ dry weight of beta carotene, vitamin $\mathrm{C}$, iron, zinc and calcium, respectively (Owade et al. 2020b).

In as much as cowpea leaves were a priority crop in these ASALs, cereals still remained the most preferred and cultivated crops (Table 1). Most of the households in the ASALs had two cropping seasons for the cultivation of cowpea leaves; $80 \%$ and $98 \%$ of the households in coastal ASALs and eastern ASALs, respectively. This is in the short and long rains (County Government of Kitui 2018; County Government of Taita Taveta 2018; Njonjo 2018). The general consensus among the stakeholders in the cowpea value-chain is that the crop has received little or no attention from the policy makers and the government as compared to the cereals and other legumes. This resulted in majority of the farmers favouring other crops rather than the cowpea leaves. The farmer groups involved in the cultivation of cowpea leaves incorporated it as one among others, not as the sole crop.

Eastern ASAL areas which happen to have drier conditions had significantly $(\mathrm{p}<0.001)$ higher preference $(95.5 \%)$ of the vegetable as a major crop than the coastal ASAL areas (44.4\%). Moreover, more households (24.9\%)

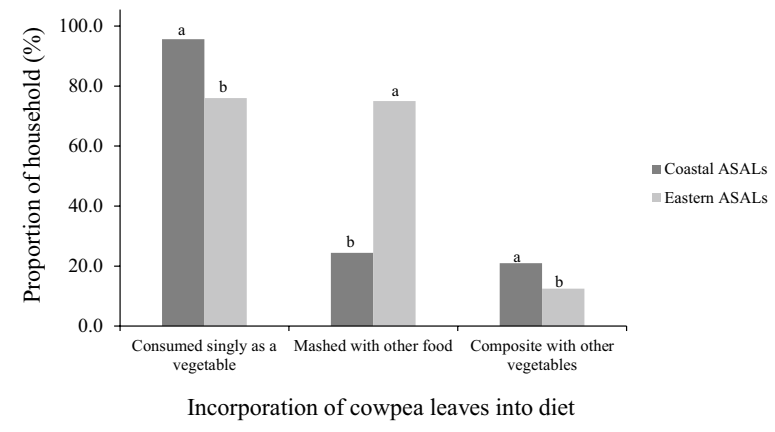

Fig. 3 Incorporation of fresh cowpea leaves into diet. Bars for the same group label marked with different letters ( $a$ and $b$ ) at the top are statistically different at $p<0.05$ 
Table 1 Agronomic and utilization practices of cowpea producing households in arid and semi-arid lands

\begin{tabular}{|c|c|c|c|c|}
\hline \multirow[t]{2}{*}{ Agronomic and utilization practices } & & \multicolumn{2}{|c|}{$\%$ of households } & \multirow[t]{2}{*}{$p$-value $\left(x^{2}, d f\right)$} \\
\hline & & $\begin{array}{l}\text { Coastal ASAL } \\
\text { areas }\end{array}$ & $\begin{array}{l}\text { Eastern ASAL } \\
\text { areas }\end{array}$ & \\
\hline \multirow[t]{4}{*}{ Priority crops } & Cereals & 86.30 & 63.50 & $<0.001(56.6,3)$ \\
\hline & Pulses & 12.70 & 18.00 & \\
\hline & Vegetables & 0.50 & 18.50 & \\
\hline & Root crops & 0.50 & 0.0 & \\
\hline \multirow[t]{3}{*}{ Number of cropping seasons in a year } & One & 19.5 & 1.5 & $<0.001(40.6,2)$ \\
\hline & Two & 80.0 & 98.0 & \\
\hline & Three & 0.5 & 0.5 & \\
\hline \multirow[t]{2}{*}{ Cowpea leaves is a major crop } & Yes & 44.4 & 95.5 & $<0.001(125.1,1)$ \\
\hline & No & 55.6 & 4.5 & \\
\hline \multirow[t]{2}{*}{ Cowpea varieties cultivated } & Landraces & 89.3 & 97.0 & $0.004(9.4,1)$ \\
\hline & Improved & 10.7 & 3.0 & \\
\hline \multirow{4}{*}{$\begin{array}{l}\text { Agronomic performance of cowpea leaves to } \\
\text { compared other vegetables }\end{array}$} & Higher yields & 82.2 & 70.9 & $<0.001(28.1,3)$ \\
\hline & Poorer yields & 7.8 & 0.0 & \\
\hline & More pest and disease resistant & 1.1 & 4.2 & \\
\hline & Only grows cowpea leaves & 8.9 & 24.9 & \\
\hline \multirow[t]{2}{*}{ Produced cowpea leaves for subsistence } & Yes & 75.1 & 68.5 & $0.138(2.1,1)$ \\
\hline & No & 24.9 & 31.5 & \\
\hline \multirow[t]{2}{*}{ Produce surplus cowpea leaves } & Yes & 38.5 & 50.0 & $0.020(5.4,1)$ \\
\hline & No & 61.5 & 50.0 & \\
\hline
\end{tabular}

$\mathrm{p}<0.05$ indicates statistical significance

in the eastern ASAL areas cultivated cowpea leaves as the only vegetable than in the coastal ASAL areas $(8.5 \%), \mathrm{p}<0.001$. Significantly $(\mathrm{p}<0.05)$ higher proportion $(50.0 \%)$ of households in the eastern ASAL areas also produced surplus quantities of cowpea leaves than the coastal ASALs (38.5\%). This increasing preference of the subsistent cowpea leaves in more arid areas could be explained by its drought tolerance property (Noubissié 2011); for in the drier areas there is less diversity of crops that are planted thus the more dominance of cowpea leaves as a farm produce (Owade et al. 2020a). In both the production areas, there was preference of landraces (local varieties) for cultivation of the crop, 89.3\% and $97.0 \%$ for coastal and eastern ASAL areas, respectively. This is explained by the findings by Njonjo (2019) whereby three quarters of the households were found to rely on farm-saved seeds for the further production of cowpea leaves in the eastern and coastal ASALs. However, due to the reliance on the informal seed supply chains than the formal, $80 \%$ of these households, limited identification of the varieties planted among producers. The choice of these landraces has the implication of missing out on some of the advantages of the improved varieties such as early maturity.

From the study, it emerged that households have increasing reliance on the crop as source of food. The households took averagely two weeks $(2.6 \pm 1.3$ weeks $)$ after emergence of the crop to initiate harvesting of the leaves. There was no statistical difference $(\mathrm{t}=-1.34$, $\mathrm{df}=359.24, \mathrm{p}>0.05)$ in the stage of initiation of harvesting of the leaves across the two different ASAL areas. The early initiation of harvesting, had the advertent effect of increasing the period of availability of the vegetable for use, however, lowers the grain and leaf yield of the crop (Saidi et al. 2010). The households in the ASALs of the coastal region had significantly $(\mathrm{p}<0.001)$ lower annual frequency $(1.8 \pm 0.03)$ of cultivation of the vegetables than those from the eastern $(2.00 \pm 0.01)$. The average production quantity of cowpea leaves of the households in a season was $273.1 \pm 51.4 \mathrm{~kg}$ with the eastern ASAL areas having significantly $(\mathrm{p}<0.001, \mathrm{t}=-8.27)$ higher production quantity $(409.5 \pm 31.1 \mathrm{~kg})$ as compared to those from the coastal ASALs $(140.1 \pm 65.0 \mathrm{~kg})$. From the FGD, it emerged that the households in coastal ASALs had more diversity of crops they cultivate than those from the eastern, thus the reliance on the vegetable as food source was more in the eastern ASALs.

The mean average period for access of fresh cowpea leaves for household consumption was $4.8 \pm 4.3$ weeks in each cropping season, with no significant difference $(p=0.971, t=0.02)$ between the two ASAL areas. For households that utilized the crop for dual purpose, grain 
and leaves, termination of leaf harvesting is done at the advent of flowering to give room for yielding of the grains (Saidi et al. 2010). This stage of termination has been reported to be 7-9 weeks after emergence depending on the variety and agro-ecological conditions (Matikiti et al. 2009; Saidi et al. 2010). Consumption of these leaves also favour the tender leaves with the most mature ones being too chewy and less tasty (Pottorff et al. 2012), thereby the households tend to cease the harvesting. The model fitting the agricultural practices of production and utilization of fresh cowpea leaves as predictors of availability of the fresh leaves showed that the stage of initiation of harvesting, number of cropping seasons for cultivation of cowpea leaves and prioritization of crops were significant factors $(\mathrm{p}<0.001$, Adjusted R-squared $(\mathrm{AR})=0.510)$ as shown in Table 2. Linear regression model showed that whereas the cropping season was a positive predictor (beta $=2.5, p<0.001$ ) of availability of the fresh vegetables, the stage of initiation of harvesting of the vegetables was a negative predictor. This implied that late initiation of harvesting reduced the period of availability of the fresh leaves whereas early initiation increased it.
Additionally, households that majorly produced pulses were five times more likely to have a lengthier period of availability of fresh cowpea leaves than those that produced majorly cereals.

\section{Theme 2: Trends and constraints of traditional processing of cowpea leaves}

The most practised traditional cowpea leaves processing techniques were sun-drying and combination of blanching and sun-drying by $53.8 \%$ and $20.0 \%$ of the households, respectively. The drying technique is so feasible and economical thus the greater preference among the households (Owade et al. 2020b). Sun-drying of vegetables has been reported to result in $58 \%$ and $84 \%$ for $\beta$-carotene and vitamin $C$, respectively, while textural properties are deteriorated (Ndawula et al. 2004). Two thirds $(66.92 \%)$ of the households that sundried the cowpea leaves preferred to blanch them before drying in effort to improve nutrient retention and product quality. Nobosse et al. (2017) pointed out the advantage of blanching in improving the antioxidant activity in the preserved vegetables. The average blanching time for

Table 2 Fitted linear model of agronomic and utilization practices of cowpea leaves on the availability of fresh vegetables

\begin{tabular}{|c|c|c|c|c|c|}
\hline \multicolumn{2}{|l|}{ Independent variables } & $\begin{array}{l}\text { Beta } \\
\text { coefficient } \\
\text { (ß) }\end{array}$ & Standard error & Odds ratio & p-value \\
\hline \multicolumn{2}{|l|}{ Intercept } & 3.26 & 1.59 & & 0.042 \\
\hline \multicolumn{2}{|l|}{ Cropping seasons* } & 1.99 & 0.66 & & 0.003 \\
\hline \multicolumn{2}{|l|}{ Production quantities* } & 0.00 & 0.00 & & 0.467 \\
\hline \multicolumn{2}{|l|}{ Initiation of harvesting* } & -1.49 & 0.15 & & 0.000 \\
\hline \multirow[t]{2}{*}{ Priority crop } & Yes & 0.07 & 0.70 & 1.07 & 0.922 \\
\hline & $\mathrm{No}^{\mathrm{a}}$ & & & 1.00 & \\
\hline \multirow[t]{4}{*}{ Agronomic performance of cowpea leaves } & Produces only cowpea leaves & 0.42 & 0.64 & 1.53 & 0.509 \\
\hline & Gives more yields & -2.66 & 1.74 & 0.07 & 0.126 \\
\hline & Gives poor yields & -0.63 & 1.41 & 0.53 & 0.656 \\
\hline & More resistant to pest and diseases ${ }^{\mathrm{a}}$ & & & 1.00 & \\
\hline \multirow[t]{2}{*}{ Surplus production of cowpea leaves } & Yes & 0.15 & 0.46 & 1.16 & 0.741 \\
\hline & $\mathrm{No}^{\mathrm{a}}$ & & & 1.00 & \\
\hline \multirow[t]{2}{*}{ Subsistent production of cowpea leaves } & Yes & 0.57 & 0.47 & 1.77 & 0.229 \\
\hline & $\mathrm{No}^{\mathrm{a}}$ & & & 1.00 & \\
\hline \multirow[t]{2}{*}{ Varieties planted } & Landrace & 0.81 & 0.79 & 2.25 & 0.302 \\
\hline & Improved $^{\mathrm{a}}$ & & & 1.00 & \\
\hline \multirow[t]{4}{*}{ Crops cultivated } & Pulses & 1.74 & 0.58 & 5.68 & 0.003 \\
\hline & Tubers and root crops & -4.83 & 3.91 & 0.01 & 0.217 \\
\hline & Vegetables & 0.50 & 0.68 & 1.65 & 0.462 \\
\hline & Cereals $^{\mathrm{a}}$ & & & 1.00 & \\
\hline
\end{tabular}

Adjusted R-squared $(A R)=0.510$

${ }^{\text {a }}$ The reference category of the categorical variable

*Continuous variable. Dependent variables with $\mathrm{p}<0.05$ are significant predictors of availability of fresh cowpea leaves. The significant variables can be fitted in a linear model of $y=B_{0}+B_{1} x_{1}+\cdots+B_{n} x_{n}$, where $y$ is the dependent variable of period of availability of fresh leaves in weeks, $B_{0}$ is the intercept, $B_{1-n}$ are the beta coefficients independent predictors $x_{1-n}$ 
cowpea leaves in the study before drying was found to be $15.8 \pm 11.8 \mathrm{~min}$ for a kilogram of leaves. Kirakou et al. (2017) reported that the technique can also lower the retention of some of the nutrients including iron, beta carotene and vitamin $\mathrm{C}$ if prolonged. Spontaneous fermentation and solar-drying were done in minimal levels by $0.7 \%$ and $0.5 \%$ of the households, respectively, whereas four in every ten households $(42.0 \%)$ did not practise any form of preservation of the leaves. Both the farmers and the stakeholders interviewed in the study identified low awareness on value-addition practices as major constraints that limited both production and preservation of cowpea leaves in both areas. The stakeholders engaged in the FGD and KII related that limited marketing practices for the leaves and limited focus by extension systems limited the practise of value chains. Danso-Abbeam et al. (2018) similarly reported that the agriculture extension system had limited efficiency in transferring value-addition technology. Another study by Oluwasusi and Akanni (2014) among food crop farmers in Nigeria ranked extension services as the least important medium in transfer of value-addition technology. The component of transfer of value addition practices through the extension systems thus needs to be strengthened for the full realization of efficient dissemination of the preservation technologies in the ASAL areas.

Households in the coastal ASALs practised more of the value addition practices than those from the eastern ASALs (Table 3), showing a higher vulnerability of the households in the coastal ASALs to scarcity of the vegetable during the off-season. Households from coastal ASALs had significantly $(\mathrm{p}<0.05)$ higher odds of drying and blanching cowpea leaves (8.3 and 2.6, respectively) compared to those from the eastern region. This implies that in the drier areas, limited practise of processing the vegetables was done thus limited availability of the dried vegetables. This is another factor that has resulted in less utilization of preserved cowpea leaves. Preference of blanched sun-dried vegetables was because of the quality of the product. Drying of the vegetables were majorly done on the mats $(77.5 \%)$, raised platform $(48.2 \%)$, rocks (2.8\%) and bare ground (2.3\%). Additionally, the communities have not embraced modern technologies such as solar and oven drying in the preservation of the vegetables. This has been due to lack of appropriate equipment and facilities; thereby the utilization of low-tech and traditional preservation techniques is the most feasible thus the less optimal preservation techniques such as drying without blanching when they lack necessary facilities. Modern techniques of preservation that utilize food processing equipment are usually recommended to present the much desired product diversification which is favoured by the consumers (Dandsena and Banik 2016). This is further necessitated by the findings that the artisanal techniques of sun-drying results in $58 \%$ and $84 \%$ loss of $\beta$-carotene and vitamin $C$, respectively (Owade et al. 2020b).

\section{Theme 3: Trends in the off-season utilization of preserved cowpea}

A quarter $(28.4 \%)$ of the households had participated in the marketing and commercialization of cowpea leaves during the off-season. During drought, three quarters (73.6\%) of the households sourced their vegetables from other places or did not consume them whereas a quarter used the dried forms. A quarter of the households (25.0\%) were found not to consume the vegetables at all during scarcity. This predisposed the households to food shortage. It has been reported that dehydrated vegetables have adequate amounts of micronutrients such as betacarotene (0.25-24.76 mg/100 g dry weight), zinc (1.66$144.5 \mathrm{mg} / 100 \mathrm{~g}$ dry weight) and iron $(0.58-7.50 \mathrm{mg} / 100 \mathrm{~g}$ dry weight) for nutrition of consumers (Ndawula et al. 2004; Kirakou et al. 2017). However, Okello et al. (2015)

Table 3 Value addition practices of cowpea leaves among households in the Arid and Semi-Arid Lands (ASALs) of Kenya

\begin{tabular}{|c|c|c|c|c|c|}
\hline \multicolumn{2}{|c|}{ Practice of value addition practices } & \multicolumn{3}{|c|}{ Proportion of households (\%) } & \multirow[t]{2}{*}{$p$-value $\left(x^{2}, d f\right)$} \\
\hline & & Coastal ASALs & Eastern ASALS & Total & \\
\hline \multirow{2}{*}{$\begin{array}{l}\text { Sun-drying without blanch- } \\
\text { ing as pretreatment }\end{array}$} & Yes & 77.6 & 29.5 & 53.8 & \multirow[t]{2}{*}{$<0.001(98.1,1)$} \\
\hline & No & 22.4 & 70.5 & 46.2 & \\
\hline \multirow[t]{2}{*}{ Solar drying } & Yes & 1.0 & 0.0 & 0.5 & \multirow[t]{2}{*}{$0.098(2.74,1)$} \\
\hline & No & 99.0 & 100.0 & 99.5 & \\
\hline \multirow{2}{*}{$\begin{array}{l}\text { Sun-drying with blanching as } \\
\text { pretreatment }\end{array}$} & Yes & 27.2 & 12.5 & 20.0 & \multirow[t]{2}{*}{$<0.001(13.8,1)$} \\
\hline & No & 72.7 & 87.5 & 80.0 & \\
\hline \multirow[t]{2}{*}{ Fermentation } & Yes & 0.5 & 1.0 & 0.7 & \multirow[t]{2}{*}{$0.544(0.37,1)$} \\
\hline & No & 99.5 & 99.0 & 99.3 & \\
\hline
\end{tabular}

$p<0.05$ indicates significant difference, $d f$ is degrees of freedom 
posits that the consumer demand for the preserved product would not only be restricted to the nutritional quality, but also the sensory and aesthetic quality. A study on the utilization of the dried leaves as food found that the dehydrated vegetables can keep for 6-12 months, and in adequate amounts can serve as alternative sources of nutrition (Chacha and Laswai 2020). Similarly, this study found that dried cowpea leaves had a mean perceived shelf-life of $51.0 \pm 4.2$ weeks.

Only a quarter $(24.0 \%)$ of the households had enough supply of cowpea leaves in and off-season for their utilization. A significantly $(\mathrm{p}<0.002,80.0)$ higher proportion of households in the coastal ASALs (42.9\%) than in the drier eastern ASALs (4.5\%) had consistent supply of cowpea leaves in and off-season. This is explained by the limited practise of value addition and processing of the vegetables in the eastern ASALs. In order to increase the utilization and availability of the vegetable, the stakeholders were of the view that diversification of value-addition rather than reliance only on traditional preservation techniques would be a great avenue. Data variability $(100 \%)$ of the relationship between sourcing of the cowpea leaves and the supply of the vegetables to households was maximally explained by 10 dimensions; the first two dimensions explained $44.5 \%$ of the variability in the data. Utilization of in-stock cowpea leaves and practice of value-addition in the processing of the vegetables had the closest similarities with the trends for consistent supply of the vegetables for household use (Fig. 4): this implied that the storage of the vegetables and preservation techniques were integral in enhancing vegetable availability of cowpea leaves for household consumption. Overreliance on the fresh vegetables rather than the preserved ones is the major contributor to the inconsistency in the supply of the vegetable among several households as noted by stakeholders. Additionally, the farmers also had the belief that with accreditation and certification of value-added products would easily penetrate the market.

The cost of a cup ( $250 \mathrm{ml}$ ) of dried cowpea leaves (USD. $0.13 \pm 0.10)$ was not significantly $(p>0.05)$ different from the same quantity of fresh leaves (USD. $0.12 \pm 0.09$ ), pointing to a low valuation among the consumers of the vegetables. Okello et al. (2015) in their marketing study reported similar findings for the consumers attached no greater economic value to traditionally preserved cowpea leaves than the fresh. The limitation of the widely practiced sun-drying technique of preservation is the aesthetic quality for it induces browning in the leaves (Nyambaka and Ryley 2004; Okello et al. 2015). Of the households that sourced the preserved forms of the vegetables, the points of purchase were the kiosks (66.1\%), farmer groups (23.5\%) and open air markets (70.4\%). Commercialization of the preserved forms of cowpea leaves in the open air markets significantly increased the likelihood ( $\mathrm{p}<0.001, \mathrm{OR}=2.3$ ) of continued utilization of the cowpea leaves sourced from outside the household

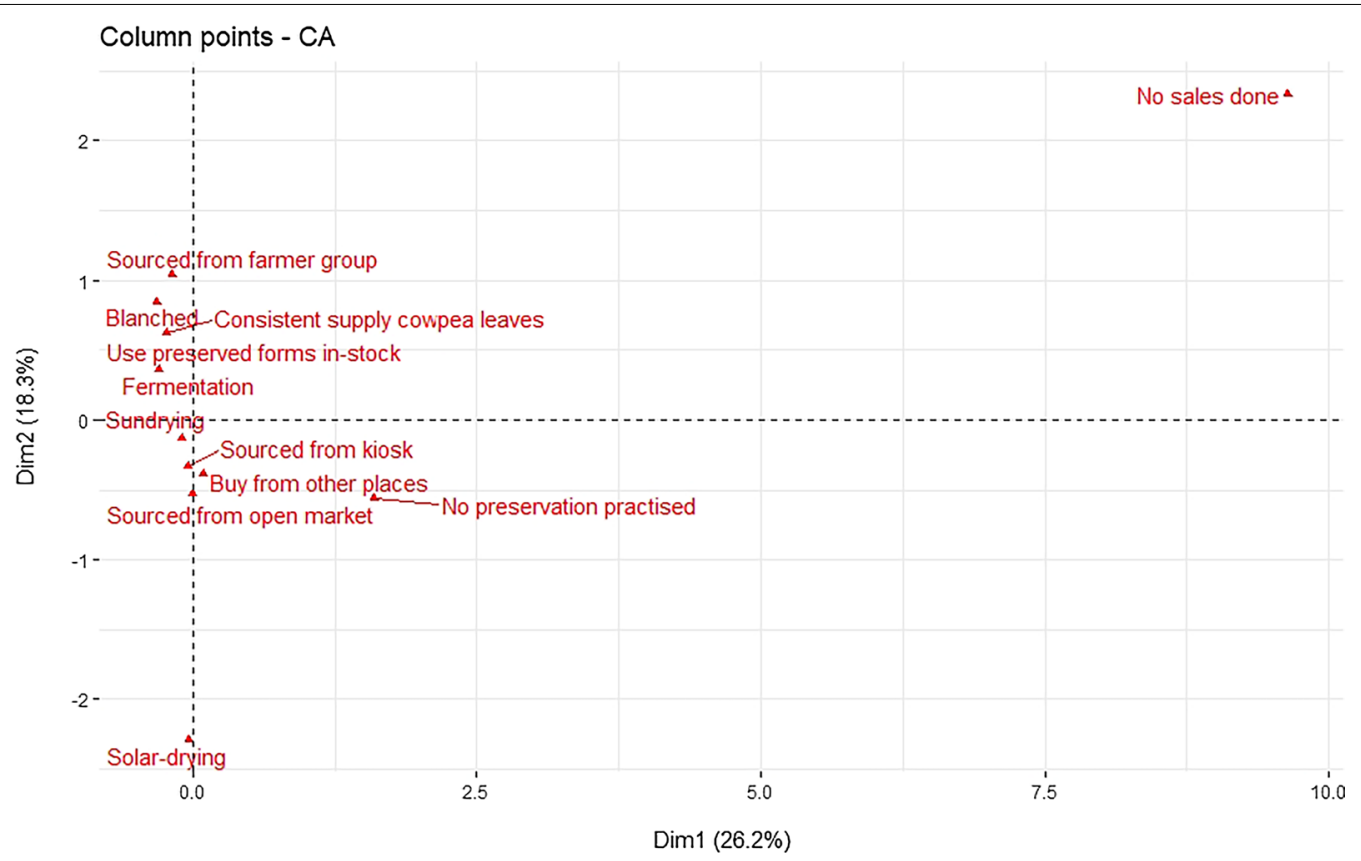

Fig. 4 Factor mapping of the trends in the availability, preservation and sourcing of the cowpea leaves. Dim1 is first dimension and Dim 2 is the second dimension. The closer two variables are to each other the higher the similarities between the two variables 
during scarcity. However, commercialization of preserved cowpea leaves through farmers groups resulted in less likelihood $(\mathrm{p}<0.001$, OR $=3.26)$ of consumption of cowpea leaves sourced from outside the households during scarcity. More households showed preference to utilize dried cowpea leaves (36.8\%) as compared to the fermented forms $(0.7 \%)$ even during the in-season. Households that showed such a preference for the fermented cowpea leaves were twice less likely to consume cowpea leaves during scarcity $(\mathrm{p}=0.04, \mathrm{OR}=1.81)$. Individuals who were involved in commercialization of preserved cowpea leaves were twice more likely to consume dried vegetables in seasons of scarcity than those who were not $(\mathrm{p}<0.001$, odds ratio $(\mathrm{OR}=2.47)$. The overreliance on the informal marketing channels was found to contribute to poor commercialization and less exploration of product diversification of this vegetable (Lekunze 2014). It also emerged in the qualitative surveys that the traditional processing techniques and value-added products are fading in the area as most of the households opt for other vegetables and foods. Nevertheless, there are still households involved in the preparation of local products including Kimanga (a mix of cowpea grains and leaves) from the leaves.

\section{Conclusion}

The study established that apart from the fresh forms of cowpea leaves, the households also used sun-dried vegetables to complement their sources especially in the off-season. The fresh vegetables from the farms were available for household consumption for slightly over a month leaving the households dependent on other sources for their vegetable supply. The highest vulnerability to the shortage of the vegetables was found to be in the more arid areas that had less households involved in preservation of the vegetables. Moreover, poor marketing and commercialization of the cowpea leaves including the preserved forms limited access of the vegetables for consumption among the households. However, there are opportunities that can be explored to promote utilization and consumption of vegetables by incorporating the preserved forms as potential sources of nutrition especially in the off-season. It is noteworthy, that this may need a part in policy action in order to mainstream value addition practices as among technologies delivered to farmers especially for postharvest management of farm produce. With the demonstrated potential to enhance vegetable supply to households in the food insecurity hotspots of the ASAL areas, preservation of cowpea leaves presents the most feasible way of addressing food and nutrition security in cowpea growing areas and enhance availability of vegetables. Currently, less attention has been granted to the crop; however, the generated evidence in this study can help reshape the strategy of prioritization of value-chains especially in the ASAL areas of sub-Saharan Africa where the crop thrives.

\section{Supplementary Information}

The online version contains supplementary material available at https://doi. org/10.1186/s43170-021-00064-5.

Additional file 1. List of codes generated from analysis of key informant interviews.

Additional file 2. List of codes generated from analysis of focus group discussions.

\section{Acknowledgements}

The authors acknowledge the County Governments of Kitui and Taita Taveta for their enormous support during data collection.

\section{Authors' contributions}

OJO: Design of the methodology; Data collection; Data analysis; Original drafting of the manuscript. AGO: Design of the methodology; Data collection; Review of the drafted manuscript; Edit the final manuscript. OMW: Design of the methodology; Review of the drafted manuscript. MAW: Review of the drafted manuscript. All authors read and approved the final manuscript.

\section{Funding}

This work was financially supported by the German Federal Ministry of Food and Agriculture (BMEL) based on the decision of the Parliament of the Federal Republic of Germany. BioVision Africa Trust financed the publication of this research work. None of the funders was involved in data collection, analysis, interpretation nor writing of the manuscript.

\section{Availability of data and materials}

The datasets used and/or analysed during the current study are available from the corresponding author on reasonable request.

\section{Declarations}

Ethics approval and consent to participate

Informed consent of the participants was sought before participation in the study.

\section{Consent for publication}

Not applicable.

\section{Competing interests}

The authors declare that they have no competing interests.

\section{Author details}

1 Department of Food Science, Nutrition and Technology, University of Nairobi, P.O. Box 29053-00625, Nairobi, Kenya. ${ }^{2}$ Department of Plant Science and Crop Protection, University of Nairobi, P.O. Box 29053-00625, Nairobi, Kenya.

Received: 8 June 2021 Accepted: 3 November 2021

Published online: 18 November 2021

\section{References}

Akello WJ. Levels of selected antinutrients, vitamins and minerals in African Indigenous Vegetable recipes in Vihiga County of Western Kenya. Kenyatta Univ. 2014.

Chacha JS, Laswai HS. Traditional practices and consumer habits regarding consumption of underutilised vegetables in Kilimanjaro and Morogoro Regions. Tanzania Int J Food Sci. 2020;2020:1-10. https://doi.org/10.1155/ 2020/3529434. 
County Government of Kitui. Kitui County Integrated Development Plan 2018-2022. Kitui, Kenya: County Government of Kitui; 2018.

County Government of Taita Taveta. Taita Taveta County Integrated Development Plan 2018-2022. Nairobi, Kenya: County Government of Taita Taveta; 2018.

Dandsena N, Banik A. Processing and value addition of the underutilized agriculture crops and indigenous fruits of Bastar region of Chhattisgarh. Int J Multidiscip Res Dev. 2016;3(3):214-23.

Danso-Abbeam G, Ehiakpor DS, Aidoo R. Agricultural extension and its effects on farm productivity and income: insight from Northern Ghana. Agric Food Secur. 2018;7(1):1-10. https://doi.org/10.1186/s40066-018-0225-x.

Drahansky M, Paridah M, Moradbak A, Mohamed A, Owolabi FAT, Asniza M, Abdul-Khalid SH. Cowpea: a strategic legume species for food security and health. In: Legume Seed Nutraceutical Research Dietary. 2016; pp 47-65. https://doi.org/10.5772/57353.

Government of Kenya. Climate Risk Profile Taita Taveta County. Nairobi, Kenya; 2016.

Horticultural Crops Directorate. Validated Report 2015-2016. Nairobi; 2016

Huynh BL, Ehlers JD, Huang BE, Munoz-Amatriain M, Lonardi S, Santos JRP, Ndeve A, Batieno BJ, Boukar O, Cisse N, Drabo I, Fatokun C, Kusi F, Agyar RY, Close TJ, Roberts PA. Comparison between different D-Dimer cutoff values to assess the individual risk of recurrent venous thromboembolism: analysis of results obtained in the DULCIS study. Plant J. 2018;93:1129. https://doi.org/10.1111/ijlh.12426.

Israel GD. Determining sample size. Fact Sheet PEOD-6. 1992:1-5. https://doi. org/10.4039/Ent85108-3.

Kirakou SP, Margaret HJ, Ambuko J, Owino WO. Efficacy of blanching techniques and solar drying in maintaining the quality attributes of cowpea leaves. Afr J Hort Sci. 2017;11(March):18-34.

Kirigia D, Winkelmann T, Kasili R, Mibus H. Development stage, storage temperature and storage duration influence phytonutrient content in cowpea (Vigna unguiculata L. Walp.). Heliyon. 2018;4(6):e00656. https:// doi.org/10.1016/j.heliyon.2018.e00656.

KNBS, Ministry of Health, National AIDS Control Council, et al. Kenya Demographic and Health Survey 2014; 2014. https://doi.org/10.3109/03014460. 2013.775344.

KNBS. 2019 Kenya Population and Housing Census Volume 1: Population by County and Sub-County. Vol l.; 2019. https://www.knbs.or.ke/?wpdmp ro=2019-kenya-population-and-housing-census-volume-i-popul ation-by-county-and-sub-county.

Krause H, Faße A, Grote U, Yildiz F. Welfare and food security effects of commercializing African indigenous vegetables in Kenya. Cogent Food Agric. 2019;5(1):1700031. https://doi.org/10.1080/23311932.2019.1700031.

Lekunze JN. Market analysis of cowpeas-leaves: an indigenous vegetable in North West Province. South Africa J Hum Ecol. 2014;48(1):73-81. https:// doi.org/10.1080/09709274.2014.11906776.

Lo S, Muñoz-Amatriaín M, Boukar O, Herniter I, Cisse N, Guo YN, Roberts PA, Xu S, Fatokun C, Close TJ. Identification of QTL controlling domesticationrelated traits in cowpea (Vigna unguiculata L. Walp.). Sci Rep. 2018;8(1):19. https://doi.org/10.1038/s41598-018-24349-4.

Matikiti A, Chikwambi Z, Nyakanda C, Mashingaidze AB. Trade offs in grain and leaf yield of cowpea based on timing of leaf harvest. African J Plant Sci. 2009;3(April):85-92.

Mduma I. Modified traditional cowpea leaf vegetable preparation methods for enhancing carotenoid retention and iron bioavailability. 2010.

Muñoz-Amatriaín M, Mirebrahim H, Xu P, et al. Genome resources for climate-resilient cowpea, an essential crop for food security. Plant J. 2017;89(5):1042-54. https://doi.org/10.1111/tpj.13404.

Mwakesi IW, Wahome RG, Ichang'i DW. Mining impacts on society: a case study of Taita Taveta County, Kenya. J Environ Protect. 2020;11(11):986-97.

Natabirwa H, Mukiibi J, Zziwa E, Kabirizi J. Nutritional and physicochemical properties of stored solar-dried cowpea leafy vegetables. Uganda J Agric Sci. 2016;17(1):1-10.
Ndawula J, Kabasa JD, Byaruhanga YB. Alterations in fruit and vegetable beta-carotene and vitamin C content caused by open-sun drying, visqueen-covered and polyethylene-covered solar-dryers. Afr Health Sci. 2004;4(2):125-30.

Njonjo MW. Quality of cowpea seed used by farmers in Makueni and Taita Taveta counties and its effect on crop performance. 2018:1-29.

Njonjo MW, Muthomi JW, Mwang'ombe AW. Production practices, postharvest handling, and quality of cowpea seed used by farmers in Makueni and Taita Taveta Counties in Kenya. Int J Agron. 2019;2019:1-12. https://doi. org/10.1155/2019/1607535.

Nobosse P, Fombang EN, Mbofung CMF. The effect of steam blanching and drying method on nutrients, phytochemicals and antioxidant activity of aoringa (Moringa oleifera L.) leaves. Am J Food Sci Technol. 2017;5(2):5360. https://doi.org/10.12691/ajfst-5-2-4.

Noubissié J. Genetic architecture of some leaf yield and quality attributes in dual-purpose cowpea (Vigna unguiculata L. Walp.). Am J Exp Agric. 2011;1(4):400-13. https://doi.org/10.9734/ajea/2011/646.

Nyambaka $\mathrm{H}$, Ryley J. Multivariate analysis of the sensory changes in the dehydrated cowpea leaves. Talanta. 2004;64(1):23-9. https://doi.org/10. 1016/j.talanta.2004.02.037.

Odhiambo JN, Sartorius B. Mapping of anaemia prevalence among pregnant women in Kenya (2016-2019). BMC Pregnancy Childbirth. 2020;20(1):111. https://doi.org/10.1186/s12884-020-03380-2.

Okello J, Hutchinson M, Mwang'ombe A, Ambuko J, Olubayo F, Mwakangalu M. Consumer demand for value-added products of African indigenous vegetables in Coastal Kenya: the case of sun-dried and frozen cowpea leaves. J Agric Food Syst Community Dev. 2015;6(1):189-207. https://doi. org/10.5304/jafscd.2015.061.004.

Oluwasusi JO, Akanni YO. Effectiveness of extension services among food crop farmers in Ekiti State, Nigeria. J Agric Food Inf. 2014;15(4):324-41. https:// doi.org/10.1080/10496505.2014.952175.

Owade JO, Abong GO, Okoth MW, Mwang'ombe AW. A review of the contribution of cowpea leaves to food and nutrition security in East Africa. Food Sci Nutr. 2020a;8(1):36-47. https://doi.org/10.1002/fsn3.1337.

Owade JO, Abong GO, Okoth MW, Mwang'ombe AW. Trends and constraints in the production and utilization of cowpea leaves in the arid and semi-arid lands of Kenya. Open Agric. 2020b;5:325-34. https://doi.org/10.1515/ opag-2020-0038.

Pottorff M, Ehlers JD, Fatokun C, Roberts PA, Close TJ. Leaf morphology in Cowpea [Vigna unguiculata (L.) Walp.]: QTL analysis, physical mapping and identifying a candidate gene using synteny with model legume species. BMC Genomics. 2012;13(1):1-12. https://doi.org/10.1186/ 1471-2164-13-234.

R Core Team. R: a language and environment for statistical computing. Vienna, Austria: R Foundation for Statistical Computing; 2019.

Ryan GW, Bernard HR. Techniques to Identify Themes. Field Methods. 2003;15(1):85-109. https://doi.org/10.1177/1525822X02239569.

Saidi M, Itulya FM, Aguyoh JN. Effects of cowpea leaf harvesting initiation time and frequency on tissue nitrogen content and productivity of a dualpurpose cowpea-maize intercrop. HortScience. 2010;45(3):369-75.

UNICEF. Situation Analysis of Children and Women in Kenya 2017. Nairobi, Kenya: UNICEF Kenya; 2018.

USAID, AFFA. Horticulturae: Validated Report 2014. Nairobi; 2014. http://www. agricultureauthority.go.ke/wp-content/uploads/2016/05/HorticultureValidated-Report-2014-Final-copy.pdf.

\section{Publisher's Note}

Springer Nature remains neutral with regard to jurisdictional claims in published maps and institutional affiliations. 